\title{
Chapter 9 \\ Education and Childlessness: The Influence of Educational Field and Educational Level on Childlessness among Swedish and Austrian Women
}

\author{
Gerda Neyer, Jan M. Hoem, and Gunnar Andersson
}

\subsection{Introduction}

Demographic research has long paid considerable attention to the connections between education and childlessness. For western countries it has regularly been shown that ultimate childlessness increases with a woman's educational level (see, e.g., Berrington et al., or Kreyenfeld and Konietzka in this volume). Researchers normally focus on individual-level explanations for this pattern, and there are competing interpretations of it. Economic theory holds that for women with more education, motherhood entails increased opportunity costs: i.e., compared to less educated women, highly educated women lose more income and human capital by concentrating on motherhood and on caregiving tasks. As a consequence, economists expect childlessness to increase with a woman's educational level (Becker 1960; Cigno 1991). Some feminist demographers have argued that having more education provides women with more economic independence and personal autonomy, and that highly educated women are therefore less likely to marry than less educated women (Oppenheimer 1994). Since unmarried women are more likely to remain childless than their married counterparts, the share of women who are childless should be higher among those who are highly educated (Kiernan 1989; Blossfeld and Huinink 1991; Hobcraft and Kiernan 1995). Theories that focus on changes in

\footnotetext{
This contribution is a modified version of the German texts by Neyer et al. (2013) and Neyer (2009). The latter were developed from Hoem et al. (2006) and Neyer and Hoem (2008). We thank Demographic Research, Zeitschrift für Familienforschung, and VUBpress for permission to use our graphs, tables, and other materials which we previously published in their journal or book.
}

G. Neyer $(\square) \bullet$ J.M. Hoem • G. Andersson

Demography Unit, Stockholm University, Stockholm, Sweden

e-mail: gerda.neyer@sociology.su.se; jan.hoem@sociology.su.se;

gunnar.andersson@sociology.su.se 
culture, values, and norms provide a third type of explanation. Researchers who take this perspective regard increasing childlessness as a consequence of a broadening range of life choices (van de Kaa 1996; Surkyn and Lesthaeghe 2004). They maintain that having more education offers women a wider spectrum of opportunities for organising their life, and that having children may thus become less important than other options (Rindfuss et al. 1996). The life course perspective offers yet another type of reasoning to explain the same general pattern: i.e., that because they spend longer periods of time in education and start employment later, women postpone motherhood, possibly up to an age at which physical fecundity may be reduced. Thus, childlessness may be expected to be higher among women who spend longer periods of time in education (Rindfuss and Bumpass 1976; Gustafsson 2001; Kravdal 2001).

However, empirical findings on childlessness for the former communist countries of Eastern Europe call into question the assumption of a monotonic relationship between educational level and childlessness. In these countries, women with more education do not necessarily have higher rates of childlessness than women with less education (Kantorova 2004; Kreyenfeld 2004). A similar conundrum is found in the Nordic countries (Andersson et al. 2009). Studies of the relationship between educational field and childlessness further complicate the picture. Findings for Sweden (Hoem et al. 2006), Norway (Lappegård and Rønsen 2005), Spain (Martín-García and Baizán 2006), Greece (Bagavos 2010), the Netherlands (Begall and Mills 2012), Germany (Maul 2012; Rösler 2012), the U.S. (Michelmore and Musick 2014), and European countries in general (Van Bavel 2010) indicate that women who have been educated to work in the education or health sector are significantly less likely to be childless than women who have been educated to work in other fields. In some cases the connection between educational field and childlessness is even stronger than the association between educational level and childlessness (Hoem et al. 2006; Van Bavel 2010).

We argue in this paper that a purely individual-level approach is not sufficient to resolve these apparent discrepancies. To find a valid explanation for the similarities and the differences in patterns of childlessness across educational groups and across countries, we need to take an institutional approach. We furthermore show that the demographic focus on family policies as the core institutional factor shaping childbearing patterns in highly developed countries is also not sufficient for explaining patterns of childlessness. We call for a comprehensive view of institutions that considers the educational system, the labour market, and family and gender policies, as well as the interactions between these institutions.

Based on this reasoning, we compare the ultimate levels of childlessness of women born in 1955-1959 in Sweden and in Austria, according to their educational level and their educational field. ${ }^{1}$ While the institutions of Sweden and Austria are similar in a number of ways, there are also essential differences in the educational

\footnotetext{
${ }^{1}$ In this contribution we use the terms educational field, educational orientation, and type of education interchangeably. The same applies to level of childlessness, rates of childlessness, and per cent childless.
} 
systems and in the labour market, in gender and family policies of the two countries. We contend that these differences have contributed to the marked differences we observe in the rates of childlessness among Austrian and Swedish women. To provide background information in support of this position, we briefly sketch in the following section the relevant country-specific aspects of the Swedish and the Austrian educational systems, and of the two countries' labour market, gender, and family policies (Sect. 9.2). We limit the information presented to the period 19701990s, when the women who were born in 1955-1959 were 15-40 years old, and were thus in their main childbearing years. In Sect. 9.3 we briefly describe the data and the methods we use in our analysis, and we present our main findings. We conclude the paper with our reflections on the possible institutional and individual-level explanations for our empirical results, and the implications of our findings for further research (Sect. 9.4).

\subsection{Sweden and Austria - Institutional Commonalities and Differences}

Because of their similarities and differences, Sweden and Austria are particularly suitable for a comparison of women's childlessness according to educational attainment. Both countries have small populations, a factor that influences their politics and policy formation process (Katzenstein 1985). Both have a long welfare tradition and can be regarded as strong welfare states in which social policies have had considerable influence on social structures. Both countries have coordinated market economies with strong employment protections for workers and employees (Estévez-Abe et al. 2001; Hall and Soskice 2001). In the 1970s and early 1980s, the Austrian federal social democratic government looked to Sweden's welfare state as a model in its efforts to modernise Austrian society (Hoem et al. 2001). The two countries have also undertaken similar family policy reforms. For example, both countries have introduced individual (rather than family-level) taxation, established legal equality between marital and non-marital children, legalised abortion in the first months of pregnancy, amended their parental leave regulations to increase women's employment, and actively promoted gender equality in many areas of public life. Moreover, in the late 1960s and early 1970s both countries reformed their educational systems to make higher education available to all social groups.

Despite these commonalities, the educational, gender, family, and social policies in Sweden and in Austria differ fundamentally in terms of their content and their aims. In political science, Sweden is classified as a proto-typical universalistic welfare state whose public policies are designed to achieve greater social and gender equality (Esping-Andersen 1990; Korpi 2000). By contrast, Austria is seen as a proto-typical conservative welfare state whose policies are designed to preserve social status differentials and perpetuate gender inequality (op cit., Marten et al. 2012). These basic orientations permeate all of the policy areas relevant to childbearing. 


\subsubsection{Sweden}

Since the 1960s, Swedish labour market and social policies have actively promoted the integration of all adults into the employment system, and particularly of mothers with (small) children. Institutional day-care facilities for children of all age groups were gradually expanded to guarantee each child a place in public child care. As a consequence, for the past 50 years Sweden has been among the European countries with the highest public childcare coverage rates for children of all age groups (Bergqvist and Nyberg 2002; Neyer 2003). Maternity protection was replaced by a gender-neutral system of parental leave which grants both parents an individual right to paid parental leave. The (paid) leave was extended successively from 6 months (1974) to 12 months (1989), and an extra non-transferable "daddy month" was added in 1995 to promote a gender-equal division of care (for details, see Duvander and Ferrarini 2010). Until the child's eighth year of life, each parent has the flexibility to take this leave on a part-time or a full-time basis, continuously or in segments, or even as individual days. Parental leave may also be combined with periods during which the parent is attending (further) education. While on parental leave, each mother or father receives an income-dependent benefit which replaces a large percentage of his or her previous income. The income replacement rate was about $90 \%$ in the 1970 s and 1980 s and was $80 \%$ thereafter, up to a fixed income ceiling. In addition to making it easier for parents to combine employment and family, Sweden has implemented comprehensive regulations to enhance gender and economic equality across all social groups. This includes the active promotion of equality in employment, wages and salaries, career advancement, professional and political representation, and education (Bergqvist et al. 1999).

The Swedish educational system is designed to be open, flexible, and supportive of social equality. It is oriented towards life-long learning (for details see Henz 2001; Halldén 2008). To ensure that as many people as possible have access to higher education, the system does not channel pupils into segregated educational streams early in their educational career. It is also relatively easy for pupils to later revise their early educational choices. Swedish primary schools provide 9 years of compulsory comprehensive education for children between the ages of seven and 16. The curriculum is largely the same for all pupils at this level. After primary school the majority of pupils enter (voluntary) upper-secondary education. If there is competition for places in certain upper-secondary programmes, the pupils' grades determine which programmes they can choose from (Erikson and Jonsson 1996). For the cohorts born in 1955-1959, upper-secondary education still encompassed both 2-year and 3-year lines of education; the 2-year lines were converted into a 3 -year line in the 1990s. The focus of the 3-year line is on theoretical knowledge. After successfully completing upper-secondary school pupils are entitled to enrol in tertiary education. The focus of most of the 2-year (and now converted 3-year) lines is on occupational and semi-occupational training. However, to ensure that students have the opportunity to change to other lines of education, a large share of the coursework is in general subjects, while practical vocational training in firms makes 
up only a small part of the course of study. By taking additional courses pupils in 2-year lines could earn the 3-year qualification needed to enrol in the tertiary educational system (Halldén 2008). Since the 1970s, admission to tertiary education has been regulated by a numerus clausus. Standardised eligibility and admission regulations are applied to all tertiary programmes and to all levels (Erikson and Jonsson 1996). Tertiary education has three levels: (1) 2- to 3-year lines of study that mainly offer advanced vocational education, (2) lines of study of at least 3-4 years that lead to a bachelor's or a master's degree, and (3) further studies that lead to a licentiate or a doctoral degree. The third level is intended to prepare the student for a scientific career.

Despite the selection process applied to upper-secondary-level and tertiary-level programmes, the Swedish educational system aims to equalise educational attainment and reduce class differentials (Erikson and Jonsson 1996). It is flexibly organised, highly permeable, and has special procedures to allow for late entry into (higher) education. Interruptions in education, moves out of and back into education, and changes in the educational line are always possible, and are often used. Individuals have a right to interrupt their employment to further their education. An extensive system of adult education and of active labour market policies facilitates and promotes (re-)education, training, and skill enhancement. Education is tuition free. A generous system of financial support, consisting of grants and loans, for individuals in higher education encourages and facilitates educational participation throughout the life course. This has resulted in high levels of educational participation and the widespread use of opportunities to earn new or improved qualifications on a flexible basis (Tesching 2012).

\subsubsection{Austria}

Austria has remained a conservative corporatist welfare state in spite of the reforms of the 1970s and early 1980s (Neyer 2003; Obinger and Tálos 2010). The education, employment, and welfare systems are not aligned as closely with the equality principles as the Swedish systems are. Austrian labour and social politics have focused more on securing the branch- and occupation-specific rights of workers and employees and on supporting the male breadwinner model than on ensuring the genderequal integration of women into the labour market or on reducing gender, social, and economic inequality (Biffl 1997). Fertility-related family policies were designed to make it easier for mothers to leave the labour market and focus full-time on caring for their children. Until 1990, parental leave lasted until the child's first birthday, and was for mothers only. In 1990, parental leave was extended to the child's second birthday, and restricted options for part-time leave and father's leave were introduced. Under a 1996 amendment 6 months of the parental leave were reserved for fathers. During the leave, previously employed mothers and fathers received a low, flat rate benefit which was independent of their previous income, but dependent on their partnership status. Because of the low benefit level and the complicated 
regulations on part-time work and on how the leave could be split between the mother and the father, parental leave was almost exclusively taken by women as full-time leave (Hoem et al. 2001; Neyer 2010). ${ }^{2}$ Until recently, there were very few childcare places for children under age three or for children of school age (Statistik Austria 2014: Table 19). Thus, many women leave their job after taking parental leave or interrupt their employment for several years.

The Austrian school system has three distinct features: the early streaming of pupils into a complex set of educational paths, the "dual system" of apprenticeship and its separation from the main educational system, and the limited options for revising previous educational choices. As in Sweden, compulsory education in Austria lasts 9 years. However, in Austria the common primary school lasts only 4 years, up to the age of ten. Thereafter, the educational lines separate, with pupils being channelled into an upper level of primary school or a lower secondary school (Hauptschule), both lasting 4 years; or into an 8-year high school (Gymnasium) with a lower-secondary and an upper-secondary level. Pupils' grades determine which type of school they can attend. To attend a Gymnasium, the pupils of our cohorts also had to pass an entrance exam. The Gymnasium and the Hauptschule are further subdivided. In the Hauptschule the pupils are grouped according to educational attainment (usually grades). In the Gymnasium pupils have to choose a specific subject line for their upper-secondary level education, such as a concentration on humanities, natural science/mathematics education, or home economics.

Pupils who have completed the Volksschule or Hauptschule or who have left the Gymnasium after completing its lower-secondary level have several options for continuing their education: (1) They can go on to a vocational middle school (berufsbildende mittlere Schule), which generally lasts 3-4 years and offers both vocational and general courses. (2) They can choose an apprenticeship (Lehre), which usually takes 3 years. The programme consists primarily of vocational training in firms, complemented by occupation-specific theoretical education in special vocational schools ("dual system"). Apprenticeships are not integrated into the "regular" educational system. ${ }^{3}$ (3) Pupils with good grades can transfer to an uppersecondary high school (Oberstufenrealgymnasium), which is a Gymnasium that only offers the upper-secondary level. ${ }^{4}$ (4) Pupils can transfer to a vocational uppersecondary high school (Berufsbildende höhere Schule) that takes 5 years to complete, and that offers vocational training together with a programme of general

\footnotetext{
${ }^{2}$ In 2002 a 3-year childrearing benefit for all mothers (or fathers) replaced the 2-year parental leave benefit for working mothers (or fathers). The regulations were subsequently amended several times, so that parents can now choose between five different variants of payment length with four flat rate benefits and one income-dependent benefit. The longest variant is the most popular one, and fathers on leave are still a minority (for details, see Marten et al. 2012).

${ }^{3}$ Unlike the general school system, which is under the auspices of the ministry of education, education for apprentices is governed by the ministry of economic affairs and the social partners, particularly the regional economic chambers (Graf et al. 2012).

${ }^{4}$ In principle, a pupil can also transfer to the upper-secondary level of a Gymnasium, but due to the different curricula in the Hauptschule and the lower-secondary level of a Gymnasium, this is rarely done.
} 
education equivalent to that of the upper-secondary level of a Gymnasium. (5) Pupils who do not make use of any of the options above can attend a 1-year polytechnical school that offers a preparatory vocational education programme. Upon completion of the Gymnasium, the Oberstufenrealgymnasium, or the berufsbildende höhere Schule students take a special maturation exam (Matura). After earning their Matura qualification, students can enrol in a tertiary education institution (a university or a post-secondary vocational college).

Austria has an open university system. Most tertiary education programmes have no numerus clausus, entrance exams, or other selection processes; and students are free to choose any line of study (irrespective of their Matura grades). There are also no formal restrictions on doctoral studies. Universities do not charge tuition, and students may qualify for financial support in the form of a non-repayable scholarship, depending on their own and their parents' income. While there have been efforts to provide special scholarships to former students to resume their studies, these programmes have been less systematically developed in Austria than in Sweden.

Having the Matura diploma is an important pre-requisite for many subsequent educational options. Not only does it open the way to tertiary education; it is also a precondition for many kinds of qualified work, particularly in the public sector. The Matura thus serves as a marker that keeps educational groups and classes apart. Individuals who have completed a course of study that did not finish with the Matura have the option of attending special schools or programmes which prepare them for taking the Matura examination. Individuals may also be admitted to specific lines of tertiary education without having earned the Matura, provided they can prove (e.g., based on their employment history) that they have the qualifications for the chosen line, and pass a special admission examination. However, the availability of preparatory courses for the Matura (outside of high schools) or for the special admission examination varies from region to region, and taking them often involves considerable effort and cost.

\subsubsection{Sweden and Austria - A Comparison of Their Institutions}

There are certain aspects of the Swedish and the Austrian institutions that should be highlighted here because they appear to have especially strong effects on the relationship between education and childlessness:

First, the Austrian educational system segregates pupils at an early age, and is not organised with the purpose of giving as many people as possible access to higher education. This is mirrored in the distribution of Swedish and Austrian women born in 1955-1959 across educational levels (Table 9.1). In Austria, $31 \%$ of all women in these birth cohorts have completed no more than compulsory education. In Sweden the corresponding figure is as low as $17 \%$. Conversely, $80 \%$ of the Austrian 
Table 9.1 Distribution of Swedish and Austrian women born in 1955-1959, by educational level

\begin{tabular}{|c|c|c|c|}
\hline Sweden & Percentage & Austria & Percentage \\
\hline Compulsory school $^{\mathrm{a}}$ & 16.6 & Primary School ${ }^{\mathrm{b}}$ & 31.3 \\
\hline \multirow[t]{2}{*}{ Upper-secondary school, 2 years } & 36.0 & Apprenticeship & 27.1 \\
\hline & & Vocational middle school & 20.7 \\
\hline Upper-secondary school, 3 years & 14.7 & Gymnasium $^{\mathrm{c}}$ & 7.9 \\
\hline $\begin{array}{l}\text { Post-secondary vocational college; } \\
\text { shorter university }\end{array}$ & 20.6 & $\begin{array}{l}\text { Post-secondary vocational } \\
\text { college }\end{array}$ & 6.2 \\
\hline University level $^{\mathrm{d}}$ & 12.1 & University & 6.7 \\
\hline
\end{tabular}

Sources: Neyer and Hoem (2008) and Neyer (2009)

Note:

${ }^{\text {a }}$ Comprehensive school up to age 16

${ }^{\mathrm{b}}$ Primary school, lower-secondary school (Hauptschule), poly-technical school (up to age 15)

c Gymnasium proper, upper-secondary high school (Oberstufenrealgymnasium), vocational high school (berufsbildende höhere Schule)

${ }^{\mathrm{d}}$ University, upper tertiary and research degree

${ }^{\mathrm{e}}$ University, all levels of completion

women have no upper-secondary (Matura), post-secondary, or tertiary education, while in Sweden the corresponding figure is $53 \%$. Only $13 \%$ of the Austrian women of these cohorts have completed post-secondary or tertiary education, while among Swedish women the corresponding figure is $33 \%$.

Second, in Sweden vocational education is integrated into the educational system. It prioritises the transmission of general, "transportable" skills over occupationspecific vocational training. A considerable share (30\%) of vocational education is at the tertiary level (Culpepper 2007). Having transportable and higher-level skills makes it easier to move between the various lines of study, and facilitates occupational mobility in the labour market (Estévez-Abe et al. 2001). By contrast, the Austrian apprenticeship system is largely segregated from the general school system (Graf et al. 2012). It offers a high level of occupation-specific vocational training, but little general, non-occupation-specific or transportable coursework. Thus, pupils in Austria have difficulties moving from an apprenticeship to a general course of study or switching between apprenticeships. Only $4 \%$ of vocational education is offered at the tertiary level (Culpepper 2007). On the other hand, having firm-based training, which tends to be high-quality and standardised, can greatly ease a pupil's transition from school to work. As a consequence, unemployment rates among young people, and particularly among those who complete apprenticeships, have been much lower in Austria than in Sweden (Lindahl 2011; Lassnig 2013).

Third, the Swedish educational system is oriented towards life-long learning, and therefore provides a broader spectrum of flexible options for participating in educational programmes, for leaving and re-entering education, and for earning new qualifications or enhancing existing qualifications over the life course. Austria has a more closed system, and limits participation in education to children and young adults to a much greater extent than Sweden.

Fourth, the Swedish school system is oriented towards promoting class and gender equality, and towards minimising corresponding differentials. Despite this aim, 
levels of sex segregation by field of education have remained high (Jonsson 1999). Sex segregation is even more pronounced in Austria, where special educational lines directed at women were maintained for much longer than in Sweden. Almost one-third of all of the women who attended the Gymnasium in the 1970s and early 1980s, and more than half of all of the women who attended a vocational middle school or enrolled in an apprenticeship, were in an educational stream in which almost all of the pupils $(95 \%)$ were female. These streams had curricula with gender-stereotypical content oriented towards family work (Lassnig and Paseka 1997).

Finally, Austrian family, social, and labour market policies have been designed to encourage women to leave the labour force when they have children. Yet employment protection, social security rights and benefits, and opportunities for promotion in the labour market have largely been tied to having an uninterrupted (and mostly full-time) career. By contrast, Sweden has more consistently pursued policies aimed at helping both parents balance family and work, and at ensuring that men and women have equal career opportunities throughout the life course.

We might expect to find that such national differences influence the connection between educational attainment and childlessness. In particular, we would expect to observe that rates of childlessness are higher in Austria than in Sweden, simply because it is harder to have children and pursue employment in Austria. On the other hand, we might also expect to find that childlessness rates are lower in Austria than in Sweden because of the large share of highly educated women in Sweden and the prevalence of feminised educational fields in Austria. Moreover, it is not clear whether women with similar educational paths in the two countries have similar levels of childlessness. Rates of childlessness among women with all types of education may differ between the two countries because of institutional differences. But if we assume that preferences are more important than institutional conditions, we would expect to observe the same levels of childlessness by educational field in both countries. In the following chapters, we investigate these assumptions by analysing childlessness by educational field and educational level in greater detail.

\subsection{Childlessness According to Educational Field and Educational Level in Sweden and in Austria}

For our empirical investigation we make use of Swedish register data and of Austrian census data. ${ }^{5}$ Both provide individual-level information. We concentrate on the cohorts born in 1955-1959, because at the point in time when we carried out our analyses this was the "youngest" cohort for whom we could get data that allow us to determine whether women were childless at the end of their reproductive years (age 40 or above). The Swedish data are extracts from the country's national educa-

\footnotetext{
${ }^{5}$ For details of data content and data handling, see Hoem et al. 2006; and Neyer and Hoem 2008.
} 
tional and population registers. The educational register contains data on all of the levels of education by field that each woman completed up to 1998. The population register lists all births through 2002. For Austria, we used the national census of 2001. It contains (self-reported) information on each woman's field and highest level of education, and on her births. For both countries, our datasets contained the entire resident female population; the datasets were large enough to allow us to also study the ultimate levels of childlessness among women who had chosen educational lines with comparatively few graduates. We combined the roughly 2600 Swedish and 650 Austrian educational fields into 60 educational groups for each country. ${ }^{6}$ The groups largely correspond to the International Standard Classification of Education (ISCED) of 1997. This process made our Swedish and Austrian educational groups generally comparable. ${ }^{7}$ Because of the differences in the educational systems, the levels of education were not harmonised. In particular, Sweden does not have the Austrian differentiation between vocational middle school (berufsbildende mittlere Schule) and apprenticeship (Lehrberuf). Conversely, the Austrian data contained no differentiation of degrees at the tertiary level, while the Swedish data allow us to make this distinction.

\subsubsection{Educational Field and Childlessness}

In Figs. 9.1 and 9.2 we present the percentages of women who were childless (at ages 40+ and of the cohorts 1955-1959) in Sweden and in Austria according to their educational orientation and educational level. In both countries, women who were educated to work in the education or health care sector are less likely to be childless than women with other types of education. In Austria, only women with an education in agriculture have lower rates of childlessness than women who were educated to work in the education or health care sector at all educational levels. On the whole, women who were educated to work in the education or health care sector are not only less likely to be childless than other women with the same level of education but in a different field; they are also less likely to be childless than women who were educated in a different field but at a lower level. For instance, Austrian women with a post-secondary degree that qualifies them to teach in primary and lower-secondary

\footnotetext{
${ }^{6}$ Austria has many more educational fields than these 650 , but in many of these fields not a single woman from the cohorts born in 1955-1959 had completed a course of study. The smaller number of educational fields in our Austrian data reflects the strong concentration of women in a select group of educational fields.

${ }^{7}$ There were a few types of education in Sweden (e.g., library science and law enforcement) that did not exist (in a similar and recorded form) in Austria, and vice versa (for example, tourism studies are common in Austria, but there was no corresponding category in our Swedish data). We chose to retain educational fields in our analysis if they had been chosen by a sufficiently large number of women; or if their inclusion contributes to our understanding of the connection between education and childlessness, even if they were present in the data of only one of the two countries.
} 


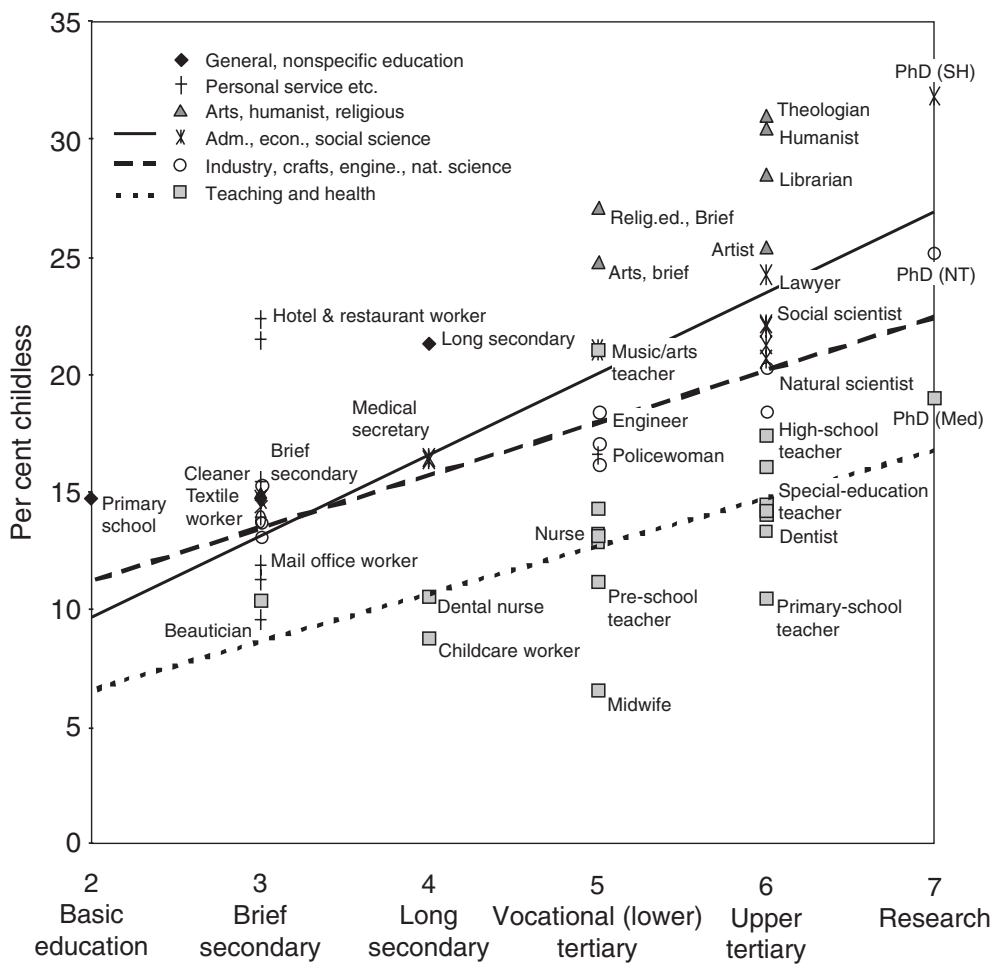

Fig. 9.1 Per cent childless in the birth cohorts 1955-1959, by educational level and educational field (Sweden) (Source: Hoem et al. 2006)

schools (Volks- und Hauptschule) are less likely to be childless (16\%) than women who had completed an apprenticeship in the beauty business, in the insurance or bank sector, or in book selling; or women who completed high school (Gymnasium) or who earned an upper-secondary vocational diploma that qualifies them to work in the textile or chemical industry, in communication technology, or in tourism. We get similar results when we compare the childlessness rates of women who were educated to work in the health care sector with the childlessness rates of women who were educated in a different field.

In Sweden, we see much larger differentials in childlessness than in Austria between women who were educated to work in the education or health care sector and women who were educated in other fields, even if they spent less time in education. Thus, Swedish women with a tertiary education that qualifies them to teach home economics or pupils with special needs $(14 \%)$ or to practice medicine as a medical doctor $(14 \%)$ have the same level of childlessness as women who left school after the compulsory minimum, or who left after earning a 2-year uppersecondary qualification without any particular vocational education.

By contrast, women who were educated in journalism, the social sciences, the humanities, theology, or the fine arts have high rates of childlessness in both 


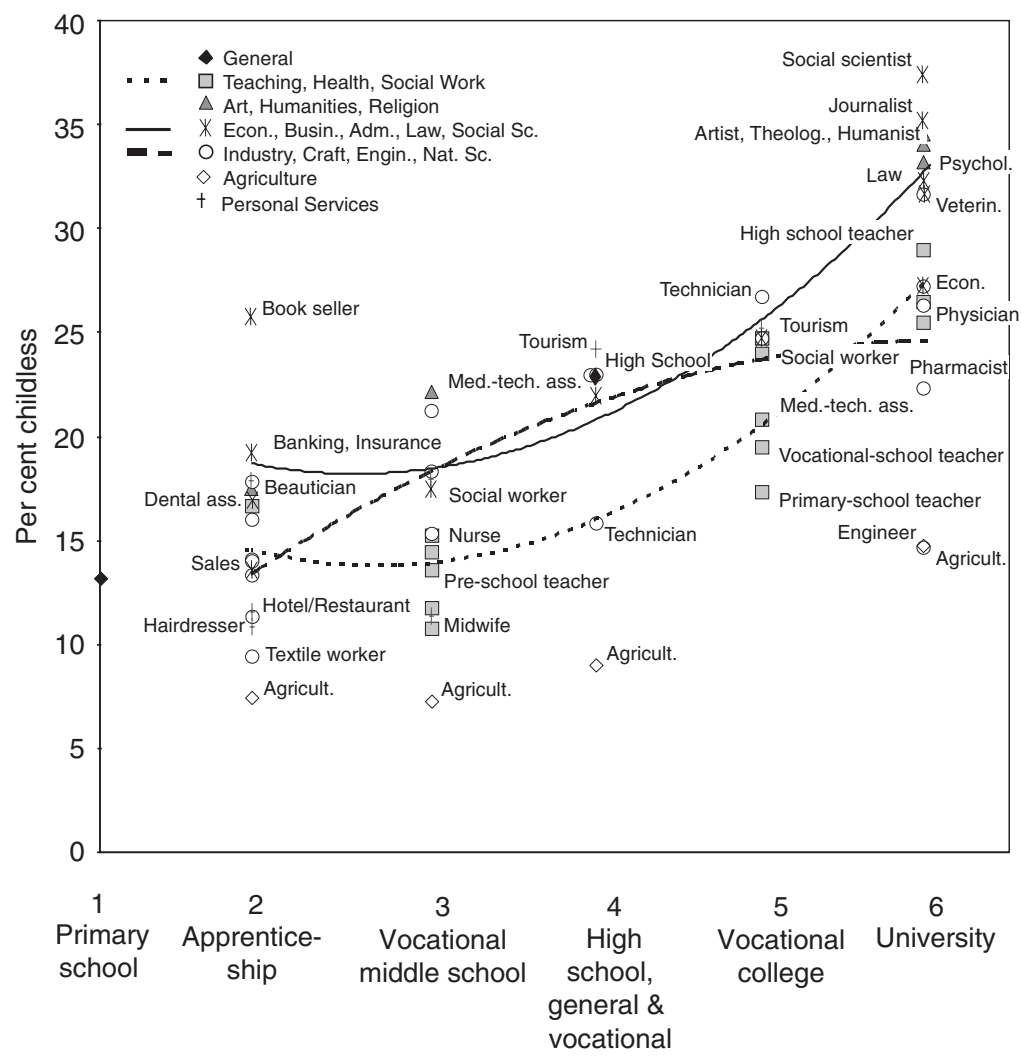

Fig. 9.2 Per cent childless in the birth cohorts 1955-1959, by educational level and educational field (Austria) (Source: Neyer and Hoem 2008)

Note: To facilitate interpretation of the figure, the trend lines refer to the larger groups of education)

countries. A woman who was educated in one of these fields (e.g., as artist or historian) is more likely to be childless than a woman with an education degree in the same field of study (e.g., as arts teacher or history teacher). Similarly, women who studied in fields closely aligned with the humanities, such as book selling (in Austria) or library science (in Sweden), are much more likely to be childless than women who were educated in other fields at the same level.

\subsubsection{Educational Level and Childlessness}

In both Sweden and Austria, the cohorts of women born in 1955-1959 have the same ultimate level of childlessness; namely, $15.7 \%$. This is somewhat surprising since we would expect to see different levels of childlessness given the institutional and educational differences in the two countries. However, national differences 


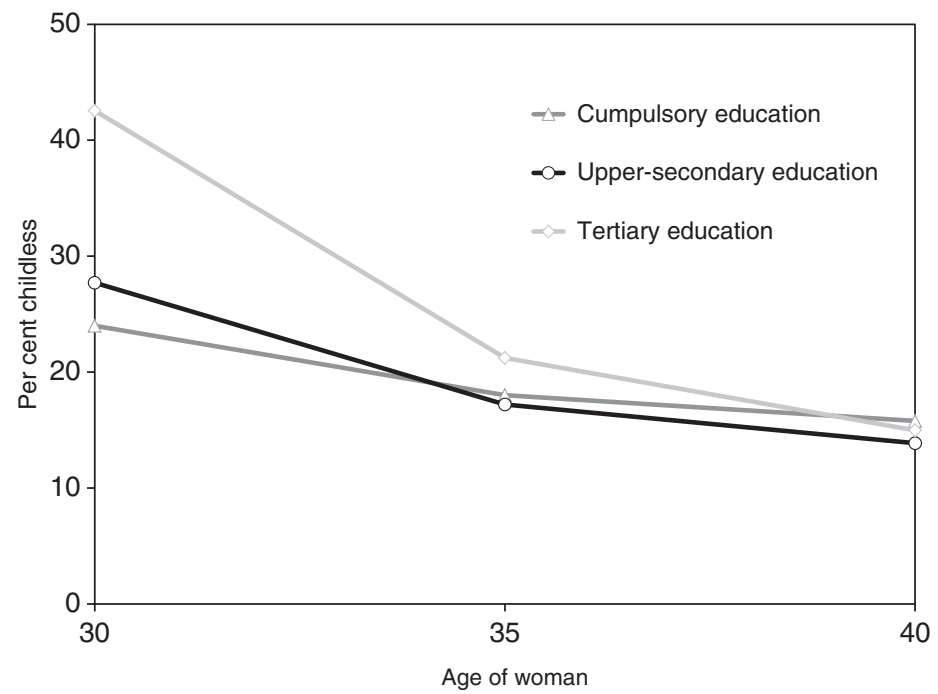

Fig. 9.3 Per cent childless by age attained and educational level, Swedish women born in 19551959 (Source: Andersson et al. 2009)

become evident when we take the level of educational attainment into account. If we only consider the three most commonly used educational levels - namely, compulsory education, secondary education, and tertiary education - we see no marked differences in childlessness between these three groups in Sweden, although the highly educated women tend to have their children later than less educated women (Fig. 9.3). Even more surprising is the finding that women with only a compulsory education have a slightly higher level of childlessness $(15.8 \%)$ than the most educated women (15.0\%) (Andersson et al. 2009).

In Austria, differences in rates of childlessness by education do not level out over the life course of women. The gap in the childlessness rates of women with only a compulsory education (13.0\%) and women with a tertiary education (23.2\%) was ten percentage points. When we use more refined groups of educational attainment (Fig. 9.4), the differences in the patterns in the two countries become even more striking. In Sweden, there are hardly any differences in rates of childlessness between women at the various levels of attainment below the advanced university levels. Only women with a master's degree (19\%) and women with a licentiate or doctorate $(25 \%)$ have higher rates of childlessness than other educational groups, but the rate of childlessness among these very highly educated women is still much lower than the rate among all tertiary-educated women in Austria (29\%). While in Sweden only women with the highest educational attainment are more likely than other women to remain childless, in Austria rates of childlessness are elevated even among women who have an upper-secondary school qualification (Matura). Onefifth $(22.2 \%)$ of the women for whom the Matura is their highest level of education remain childless; this rate is eight percentage points higher than the rate among 


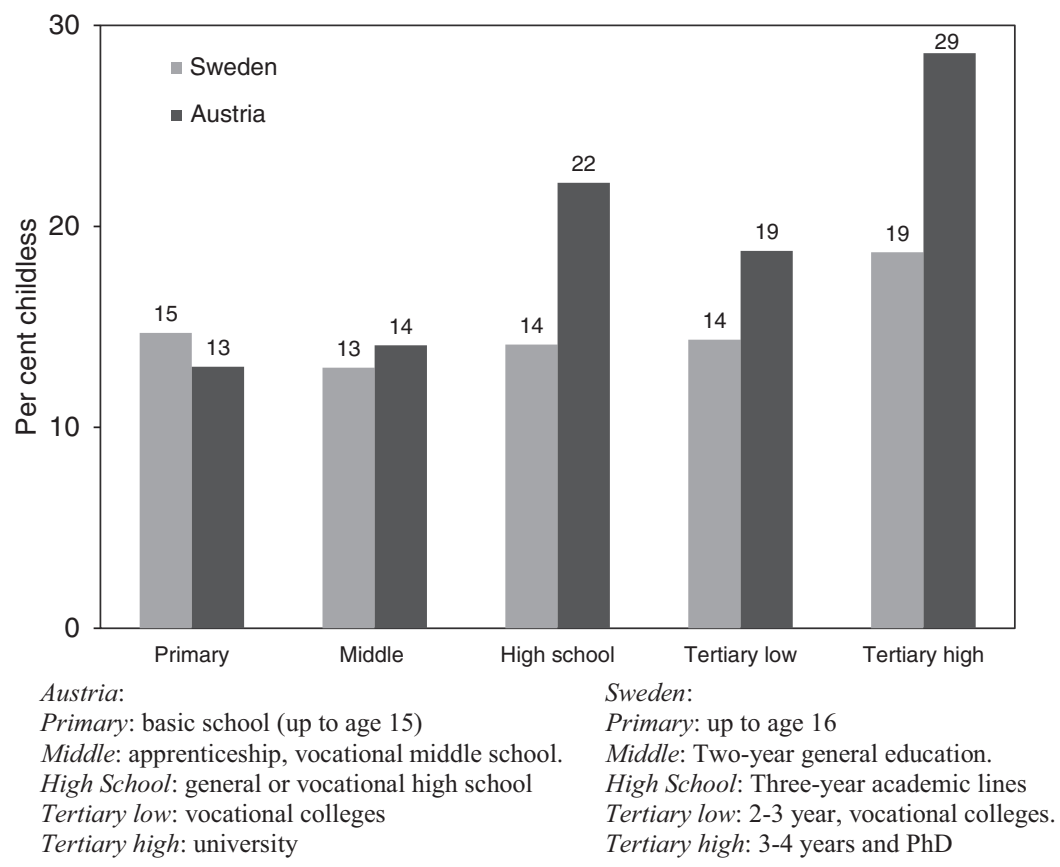

Fig. 9.4 Childlessness according to educational attainment in Sweden and in Austria (Source: Neyer and Hoem 2008)

Austrian women who completed vocational middle school or an apprenticeship, and eight percentage points higher than the rate among Swedish women with the same educational attainment. As Figs. 9.1, 9.2, and 9.4 show, childlessness increases more strongly with educational level in Austria than in Sweden. There seems to be a clearer differentiation by educational attainment in Austria at each level of attainment, with the Matura being the boundary between women with average levels of childlessness and those with much higher levels of childlessness.

The distinctly higher rates of childlessness among Austrian women with an advanced education than among the corresponding Swedish women can be seen in Table 9.2. In the table, the childlessness rates of select groups of Swedish and Austrian women with equivalent education (level and field) are presented. The patterns of childlessness among women who were educated to work in the education or health care sector most clearly demonstrate the fundamental differences between Austria and Sweden. At each level of education, Austrian women with this educational background are more likely to be childless than similar women in Sweden, even though some of the requirements for these educational levels are higher in Sweden than in Austria (e.g., for kindergarten/pre-school teachers). The most obvious differences are among women at the university level. More than one-quarter of all Austrian women with a university-level degree in education or health are childless at age 40 . Their childlessness rate is more than ten percentage points higher than that of Swedish women with the same educational background, and ten 
9 Education and Childlessness: The Influence of Educational Field and Educational...

Table 9.2 Childlessness of select groups of women by educational field and level in Sweden and Austria (per cent childless, women born 1955-1959)

\begin{tabular}{|c|c|c|}
\hline & Austria & Sweden \\
\hline \multicolumn{3}{|l|}{ Education } \\
\hline Pre-school teacher child carers & 13.5 & 11.0 \\
\hline Primary school teacher & 16.5 & 10.3 \\
\hline High school teacher & 29.1 & 17.3 \\
\hline \multicolumn{3}{|l|}{ Health } \\
\hline Midwife & 10.6 & 6.4 \\
\hline Nurse & 14.5 & 13.0 \\
\hline Medical doctor & 25.4 & 15.9 \\
\hline \multicolumn{3}{|c|}{$\begin{array}{l}\text { Education without Matura/ 2-year upper- } \\
\text { secondary education }\end{array}$} \\
\hline Beautician/hairdresser & 12.7 & 9.6 \\
\hline Textile specialist & 10.6 & 13.9 \\
\hline Apprenticeship & 9.3 & \\
\hline Vocational middle school & 15.2 & \\
\hline Hotel/restaurant business & 12.7 & 22.4 \\
\hline Apprenticeship & 11.7 & \\
\hline Vocational middle school & 17.9 & \\
\hline Home economics & 11.4 & 21.6 \\
\hline Agriculture & 7.4 & 15.5 \\
\hline \multicolumn{3}{|l|}{ University } \\
\hline Social sciences & 37.3 & 32.9 \\
\hline Theology & 33.9 & 30.9 \\
\hline Humanities & 33.1 & 30.4 \\
\hline Psychology & 32.5 & 32.7 \\
\hline \multicolumn{3}{|c|}{ Technical university/natural sciences } \\
\hline Engineers/technical professions & 14.6 & 19.0 \\
\hline Natural sciences & 26.2 & 22.0 \\
\hline
\end{tabular}

Source: Hoem et al. (2006) and Neyer and Hoem (2008)

percentage points higher than that of Austrian women who were educated in the same field but at a lower level of attainment.

There are similar differentials by educational attainment in other areas of education, such as in fields of education that prepare women to work in the textile, leather, or clothing industries; in hotels and restaurants; in tourism, or in social work. For all of these fields the fraction of Austrian women who are childless increases from around $10 \%$ among women who have completed an apprenticeship, to 15-18\% among women who have a vocational middle school qualification, and to $25 \%$ among those who have a higher vocational school qualification. In Sweden childlessness also increases with educational level, but this relationship is less strong than the relationship between educational field and childlessness (Hoem et al. 2006).

In some areas of education, the results for Austria and Sweden diverge from our initial expectations. This is particularly the case for work in the hotel and restaurant sector, in home economics, or in agriculture. Swedish women who were educated in 
these fields are considerably more likely to be childless at age 40 than their counterparts in Austria (Table 9.2, Neyer and Hoem 2008). It is not clear why this is the case. These differences may be attributable to the number of women who pursue these courses of study, or to the structure or nature of the occupations associated with these courses. For instance, more than twice as many women in Austria as in Sweden finished a middle-level certificate that qualifies them to work in the hotel and restaurant industry. The hotel and restaurant sector is much larger in Austria than in Sweden, and the vast majority of businesses are small and family-owned. Thus, many Austrian women work in their own family business. In Sweden, an education in home economics prepares students to administer large (institutional) households, while in Austria education in home economics aimed at preparing women for housekeeping and motherhood. An apprenticeship or vocational middle school qualification with an agricultural orientation is also three times more common in Austria than in Sweden, and these courses often cover home economics, as well.

As we mentioned above, the rates of childlessness among women educated in the humanities, arts, psychology, and theology are similar in Austria and Sweden. The low rates of childlessness in both countries among women who have a university degree in engineering are surprising, particularly as in Austria these women have the lowest rates of childlessness among all university graduates (15\%); even lower than those among women in the same field but with a lower qualification, and considerably lower than women with a degree in the natural sciences. (Fig. 9.2 and Table 9.2).

\subsection{Education and Childlessness: Discussion and Conclusions}

The differences and the similarities in the patterns of childlessness in Sweden and Austria lead us to ask the question of what factors produced them. The present investigation cannot give a definitive answer, because the available data only contain information about whether a woman is childless, and not about the determinants of childlessness. Nevertheless, we will outline what we believe are the most important potential determinants, with a focus on institutional aspects, especially on the educational system, the links between education and labour market, as well as on the role of individual choice and self-selection.

\subsubsection{Educational System and Childlessness}

As we have outlined, the Austrian and Swedish educational systems have very different goals and structures. The Swedish system is oriented towards promoting the educational advancement of each individual throughout her/his life course. A 
woman therefore has the flexibility to arrange her educational career so that it fits with her other life goals, including having children. It appears that women often make use of this flexibility: in almost one-third of the 60 types of educational fields we analysed, women completed their (final) educational qualification after the birth of their first child (Hoem et al. 2006). More than half of these women were educated to work in the education or health sector, or in another public sector. From the data we have available, we cannot conclude whether it is easier to combine motherhood and education in these fields than in others, or whether the effect we see is attributable to re-education or to continued education after the arrival of the first child. Tesching (2012) showed that in Sweden childless women are twice as likely as mothers to change their educational field. She also showed that mothers who were educated in a female-dominated field that leads to stable employment with strong job protections, mostly in the public sector (e.g., education, health care, and welfare), have much lower risks of changing their field of education than mothers in general and/or mothers who were educated in another field. The risk of pursuing a course of study in another field after becoming a mother is very high among women who were educated in the humanities, the social sciences, journalism, law, and the fine arts and media (Tesching 2012). These findings suggest that women who were educated in these fields find it difficult to continue to work in their chosen occupation after they have become a mother. The findings also indicate that the flexibility of the Swedish educational system, which offers women the option of continuing their education later in life or of retraining for a job that can be more easily combined with raising children, explains at least in part the lower rates of childlessness among Swedish women with specific educational backgrounds and higher educational attainment.

By contrast, as we have noted repeatedly, the Austrian educational system is closed, and is organised in a rather fixed sequential order in which education precedes employment and family formation. Thus, the educational system does not accommodate childbearing. For instance, for apprentices (of our cohorts) who were pregnant or had a child, the maternity and parental leave regulations in the workplace were not coordinated with the rules for vocational school attendance. As a consequence, it was often impossible for female students to complete their apprenticeship if they became pregnant and had a child. At all levels of education, the only way for most women to avoid dropping out was to postpone motherhood until they had completed their desired level of education.

Overall, our results suggest that a flexible educational system is more conducive to parenthood than a closed system: it seems to reduce childlessness among women with long courses of study, as becoming a parent does not threaten the student's possibility to take her final examinations. It allows women (and men) to adapt their educational field to the demands of childrearing, and it makes it easier for them to update their qualifications following interruptions. It can therefore reduce the risk that women will remain childless for educational or occupational reasons. 


\subsubsection{Education and Labour Market}

The outcomes of our investigation lead us to believe that the ways in which education and the labour market are intertwined may influence childbearing behaviour. All of these connections are underpinned by family and gender policies. On the basis of their findings for Swedish women Hoem et al. (2006) identified five clusters of education, each of which is connected to specific labour market and occupational areas. They analysed how each of these clusters leads to a different level of childlessness. The results were later partly confirmed in a cohort study for Norway by Rønsen and Skrede (2010). With our Austrian data, we can check whether the clusters hold for a conservative welfare state, as well.

\section{Educational Fields of Study That Lead to Jobs in the Public Sector}

In both Sweden and Austria, educational fields that prepare students to work in education, health, social work, and law often lead to jobs in the public sector. In both countries, the public sector offers increased job protection, a more stable and secure income, and better parental leave conditions than the private sector. We would therefore expect to find that women who were educated in fields that lead to jobs in the public sector have lower levels of childlessness. However, we find that, first, childlessness rates are lower only among women who are educated to work in female-dominated occupations in the public sector, such as education, health, and social work; whereas women who were educated to work in more male-dominated public sector areas - like law (Austria and Sweden), law enforcement, and library science (Sweden) - do not have childlessness rates that are much lower than those of other women with the same level of education (see also Ohlsson-Wijk 2015). Second, Austrian women with an upper-secondary (Matura), post-secondary, or tertiary degree in educational fields that lead to female dominated jobs in the public sector (such as a degree in high school education) are more likely to be childless than we would expect. This may be in part because for our cohorts, tenure and careers in the public sector were tied to uninterrupted, full-time employment. Taking parental leave or moving to a part-time schedule was incompatible with these requirements.

\section{Fields of Education That Lead to Feminised Occupations in the Private Sector}

Many fields of education lead to jobs in private sector industries in which most of the employees are female: e.g., the food production industry, the textile industry, business administration, personal services (such as the beauty and hairdressing business), and the hotel and restaurant industry. In both Austria and Sweden, women with these educational backgrounds are rarely childless, although there are some 
differences in childlessness rates between the countries (see Figs. 9.1 and 9.2). It appears that Swedish women are more likely to be childless if they are educated to work in an occupational field with high levels of employee turnover and with nonstandardised working hours, such as the hotel and restaurant industry; and they are less likely to be childless if they are educated to work in sectors with more standardised working conditions. In Austria these relationships seem to be inverted. One reason for this difference could be that in Austria jobs with standardised working conditions usually have higher social status, better working conditions, and higher wages. We generally find that Austrian women with educational backgrounds that lead to occupations with these characteristics are more likely to be childless than women who were educated to work in occupations with lower levels of social prestige and professional gratification.

\section{Gender-Mixed Lines of Education with Little Occupational Specialisation}

In both countries childlessness rates are above average among women who chose a gender-mixed line of education without a specific occupational profile. This category includes women who left the educational system after primary school or after a general upper-secondary education without a vocational specialisation. It also includes women with a (non-education) degree in the humanities, fine arts, or general social sciences. Women who have completed educational lines with no specific vocational qualifications tend to find it harder to enter the labour market than women who chose an occupation-specific field of education (Korpi et al. 2003; Lassnig 2013). These uncertainties seem to discourage childbearing.

\section{Gender-Mixed Lines of Education with a High Degree of Occupational Specialisation}

A broad spectrum of educational lines are assigned to this category, including preparation to work in secretarial and administrative occupations, and in sectors such as banking and insurance, business administration, business economics, law, journalism, and tourism. These women have been educated for jobs with very different employment prospects, career paths, income levels, and degrees of occupational feminisation. In both countries, women with these educational backgrounds have higher rates of childlessness than comparable women with other educational backgrounds. We assume that women who work in an occupation with a balanced gender distribution face more competition from men and greater (direct or indirect) discrimination at work than women in a more female-dominated occupation, and that these factors may discourage them from having children. 


\section{Male-Dominated Lines of Education}

Male-dominated educational lines frequently provide students with the skills needed to work in the private sector, such as in occupations related to engineering, technology, and the natural sciences. Women who are educated in these fields face greater difficulties in entering the labour market than women with other educational backgrounds: specifically, they tend to have a longer job search after completing their education, fewer secure job offers, and fewer opportunities to maintain their employment (Smyth 2003). Contrary to expectations, we find that women who were educated in a maledominated - and especially in a technical - field are slightly (Sweden) to decidedly (Austria) less likely to be childless than women who were educated in a genderbalanced field. Job uncertainties and the experiences associated with being a "token woman" may account for the particularly low result in Austria, but studies in this country have also shown that women with a technical education often have highly educated parents (Fischer-Kowalski 1985). It is possible that women with universityeducated parents find it easier than other women to combine work and family.

\subsubsection{Choice of Education, Self-Selection, and Social Environment}

The observed variations in childlessness by type of education in both Austria and Sweden suggest that women factor in their plans for having a family when they choose a specific educational line. Scholars often assume that women who want to have children tend to choose an educational field that will enable them to combine work and motherhood in their preferred form (Hakim 2000). This process may be expected to result in a concentration of women who want to have children in specific educational and occupational fields, which may in turn promote a social environment and social norms which support childrearing (Elster 1991). However, historical investigations of childlessness among women with specific types of education have shown that individual preferences play out differently in different contexts. As a consequence, the levels of childlessness among women with the same educational backgrounds may vary considerably depending on the circumstances in which these women live (Jensen 1973; Cookingham 1984). This leads us to take a more nuanced view of how self-selection and social norms may work:

First, because of the structural differences in the educational systems, the selection processes into educational lines may be quite different in Austria and in Sweden. For instance, the stronger segmentation of the educational system in Austria may mean that not every type of (secondary) education or apprenticeship was available in every region. In these circumstances, parents may send their children to the closest school, and pupils may choose an apprenticeship based on availability.

Second, differences in the organisation of the educational system, in parental leave, in childcare availability, and gender policies may lead to different selection processes. For example, in Austria women (of our cohorts) who wanted to have 
children may have tended to opt for shorter educational lines and to avoid longer courses of study. By contrast, in Sweden fertility considerations may play a smaller role in women's educational choices.

Third, the social environment during education and thereafter may lead women to change their preferences regarding childbearing, and to adjust their childbearing behaviour to the norms in their respective educational or occupational field. These shifts in attitudes and behaviour may partly explain the high rates of childlessness among women who were educated in the humanities, the fine arts, or the social sciences; as well as in library science or book selling. In the 1970s and 1980s, these disciplines generated feminist theories which raised fundamental questions about whether reproduction should be the norm for women.

Fourth, differences in social norms may explain the different distributions of childlessness in Sweden and in Austria. The largely uniform pattern of childlessness across educational levels in Sweden suggests that having children is the social norm for all women (and men) in this country, while in Austria remaining childless is a socially acceptable behaviour for highly educated women. Social pressure to have children appears to be stronger and more universal in Sweden than in Austria (Oláh and Bernhardt 2008; Prskawetz et al. 2008). The Swedish education, family, and gender policies tend to encourage conformity with the norm of having children. In Austria, there seems to be more leeway to opt out of or resist the social norm of having children, at least for the highly educated (Oláh and Hobson 2006).

\subsubsection{Education and Childlessness: Should There Be an Individual-Level or an Institutional Approach?}

As we noted in the introduction, the bulk of literature on education and childlessness stresses individual choices over institutional conditions. This may be attributable in part to the dominance of particular theories (like rational choice), but it may also be a consequence of empirical restrictions. Surveys usually contain too few cases to allow scholars to differentiate sufficiently by educational attainment, and comparative research across many countries does not allow researchers to adequately consider differences in educational systems. For our study, we had detailed information about the educational and childbearing histories of all of the women of certain cohorts in two countries. Thus, we had a dataset that was sufficiently large to allow us to distinguish between many educational lines. Focusing on two countries provided us with the opportunity to factor in the structures and the aims of the institutions that are assumed to shape childbearing behaviour. Our results clearly show that commonly reported findings on the link between education and childlessness should not be taken at face value and accepted as being indicative of universal patterns. In line with other scholars, we do not find that highly educated women have always had higher rates of childlessness than less highly educated women. Our results also do not provide unconditional support for the assumption that preferences regarding children guide women's educational choices. Instead, our findings 
support the view that institutional conditions modify preferences and behaviour. Our results also underline that an institutional approach which focuses only on family policies is too narrow to explain differentials in childlessness and fertility patterns. It is essential that one adopts a life course perspective on the role of institutions in family formation; i.e., that one considers the different institutions which shape childbearing behaviour over a person's life course. This calls for both a broadening of the institutional approach beyond family policies, as well as a more detailed consideration of institutions beyond the concept of the welfare state. Such an approach would allow scholars to link individual behaviour and institutional conditions with greater confidence, and in ways that provide us with a deeper understanding of childbearing decisions and of the variation in fertility patterns across social groups and across countries.

Acknowledgement The authors want to express their indebtedness to Britta Hoem, who started the line that we pursue in this paper, but did not live to develop her ideas into empirical research. We are grateful for financial support from the Swedish Research Council (Vetenskapsrådet) via the Linnaeus Center on Social Policy and Family Dynamics in Europe (SPaDE), grant 349-2007-8701, and the Swedish Initiative for Research on Microdata in the Social and Medical Sciences (SIMSAM), grant 340-2013-5164.

\section{Literature}

Andersson, G., Rønsen, M., Knudsen, L.B., Lappegård, T., Neyer, G., Skrede, K., Teschner, K., \& Vikat, A. (2009). Cohort fertility patterns in the Nordic countries. Demographic Research, 20, 313-352. http://www.demographic-research.org/volumes/vol20/14/20-14.pdf

Bagavos, C. (2010). Education and childlessness: The relationship between educational field, educational level, employment and childlessness among Greek women born in 1955-59. Vienna Yearbook of Population Research, 8, 51-75.

Becker, G. S. (1960). An economic analysis of fertility. In National Bureau of Economic Research (Ed.), Demographic and economic change in developed countries. A conference of the Universities-National Bureau Committee for Economic Research (pp. 209-240). Princeton: Princeton University Press.

Begall, K., \& Mills, M. (2012). The influence of educational field, occupation, and occupational sex segregation on fertility in the Netherlands. European Sociological Review, 31, 720-742.

Bergqvist, C., \& Nyberg, A. (2002). Welfare state restructuring and child care in Sweden. In S. Michel \& R. Mahon (Eds.), Child care policy at the crossroads. Gender and welfare state restructuring (pp. 287-308). New York/London: Routledge.

Bergqvist, C., Borchorst, A., Christensen, A.-D., Ramstedt-Silén, V., Raaum, N. C., Styrkársdóttir, A. (Eds.). (1999). Equal democracies? Gender and politics in the Nordic countries. Oslo: Scandinavian University Press.

Biffl, G. (1997). Schule - Wirtschaft - Frauen. In L. Lassnig \& A. Paseka (Eds.), Zum Geschlechterverhältnis im Bildungswesen (pp. 234-239). Innsbruck: Studienverlag.

Blossfeld, H.-P., \& Huinink, J. (1991). Human capital investment or norms of role transition? How women's schooling and career affect the process of family formation. American Journal of Sociology, 97, 143-168.

Cigno, A. (1991). Economics of the family. Oxford: Clarendon Press.

Cookingham, M. E. (1984). Bluestockings, spinsters and pedagogues: Women college graduates, 1985-1910. Population Studies, 38, 349-364. 
Culpepper, P. D. (2007). Small states and skill specificity. Austria, Switzerland, and interemployer cleavages in coordinated capitalism. Comparative Political Studies, 40, 611-637.

Duvander, A.-Z., \& Ferrarini, T. (2010). Earner-carer model at the crossroads: Reforms and outcomes of Sweden's family policy in comparative perspective. International Journal of Health Services, 40, 373-398.

Elster, J. (1991). Rationality and social norms. Archive Européenne de Sociologie, 32, 109-129.

Erikson, R., \& Jonsson, J. O. (1996). The Swedish context: Educational reform and long-term change in educational inequality. In R. Erikson \& J. O. Jonsson (Eds.), Can education be equalized? The Swedish case in comparative perspective (pp. 65-93). Boulder: Westview Press.

Esping-Andersen, G. (1990). The three worlds of welfare capitalism. Princeton: Princeton University Press.

Estévez-Abe, M. (2005). Gender bias in skills and social policies. The varieties of capitalism perspective on sex segregation. Social Politics, 12, 180-215.

Estévez-Abe, M., Iversen, T., \& Soskice, D. (2001). Social protection and the formation of skills. A reinterpretation of the welfare state. In P. Hall \& D. Soskice (Eds.), Varieties of capitalism. The institutional foundation of comparative advantage (pp. 143-184). Oxford: Oxford University Press.

Fischer-Kowalski, M. (1985). Bildung. Bericht über die Situation der Frau in Österreich. Frauenbericht 1985. Band 2. Wien: Bundeskanzleramt.

Graf, L., Lassning, L., \& Powell, J. (2012). Austrian corporatism and institutional change in the relationship between apprenticeship training and school-based VET. In M. Busemeyer \& C. Trampusch (Eds.), The political economy of collective skill formation (pp. 150-178). Oxford: Oxford University Press.

Gustafsson, S. (2001). Optimal age at motherhood. Theoretical and empirical considerations on postponement of maternity in Europe. Journal of Population Economics, 14, 225-247.

Hakim, C. (2000). Work-lifestyle choices in the 21st Century. Preference theory. Oxford: Oxford University Press.

Hall, P., \& Soskice, D. (Eds.). (2001). Varieties of capitalism. The institutional foundation of comparative advantage. Oxford: Oxford University Press.

Halldén, K. (2008). The Swedish educational system and the ISCED-97. In S. Schneider (Ed.), The International Standard Classification of Education. An evaluation of content and criterion validity in 15 European countries (pp. 253-267). MZE: Mannheim.

Henz, U. (2001). Family formation and participation in higher education: cross-cutting life events? In J. O. Jonsson \& C. Mills (Eds.), Cradle to grave. Life-course change in modern Sweden (pp. 45-69). Durham: Sociology Press.

Hobcraft, J., \& Kiernan, K. (1995). Becoming a parent in Europe. Welfare state program discussion paper series No. 116. London: Suntory and Toyota International Centres for Economics and Related Disciplines.

Hoem, J. M., Neyer G., \& Andersson, G. (2006). Education and childlessness. The relationship between educational field, educational level, and childlessness among Swedish women born in 1955-59. Demographic Research, 14, 331-380. http://www.demographic-research.org/volumes/vol14/15/14-15.pdf

Hoem, J. M., Prskawetz, A., \& Neyer, G. (2001). Autonomy or conservative adjustment? The effect of public policies and educational attainment on third births in Austria. Population Studies, 55, 249-261.

Jensen, R. (1973). Family, career, and reform. In M. Gordon (Ed.), The American family in socialhistorical perspective (pp. 267-280). New York: St. Martin's Press.

Jonsson, J. O. (1999). Explaining gender differences in educational choice: An empirical assessment of a rational choice model. European Sociological Review, 15, 391-404.

Kantorova, V. (2004). Education and entry into motherhood. The Czech Republic during state socialism and the transition period (1970-1997). In G. Andersson \& G. Neyer (Eds.), Contemporary research in European fertility. Perspectives and developments (pp. 246-270). Demographic Research. Special Collection 3, http://www.demographic-research.org/special/3/10/s3-10.pdf

Katzenstein, P. (1985). Small states in world politics. Ithaca: Cornell University Press. 
Kiernan, K. (1989). Who remains childless? Journal of Biosocial Science, 21, 387-398.

Korpi, W. (2000). Faces of inequality. Gender, class, and patterns of inequality in different types of welfare states. Social Politics, 7, 127-189.

Korpi, W., de Graaf, P., Hendrickx, J., \& Layte, R. (2003). Vocational training and career employment. Precariousness in Great Britain, the Netherlands and Sweden. Acta Sociologica, 46, $17-30$.

Kravdal, Ø. (2001). The high fertility of college educated women in Norway. An artifact of the separate modeling of each parity transition. Demographic Research, 5, 187-216. http://www. demographic-research.org/volumes/vol5/6/5-6.pdf

Kreyenfeld, M. (2004). Fertility decisions in the FRG and GDR. An analysis with data from the German Fertility and Family Survey. In G. Andersson \& G. Neyer, (Eds.), Contemporary research in European fertility. Perspectives and developments (pp. 275-318). Demographic Research. Special Collection, 3. http://www.demographic-research.org/special/3/11/s3-11.pdf

Lappegård, T., \& Rønsen, M. (2005). The multifaceted impact of education in entry into motherhood. European Journal of Population, 21, 31-49.

Lassnig, L. (2013). Austria's success on the youth labour market - not systematic but voluntaristic. Lifelong Learning in Europe (LLineE), http://www.lline.fi/en/article/policy/20135/ what-are-they-doing-right-3-cases\#title0

Lassnig, L., \& Paseka, A. (Eds.). (1997). Zum Geschlechterverhältnis im Bildungswesen. Innsbruck: Studienverlag.

Leitner, S. (2003). Varieties of familialism. European Societies, 5, 353-375.

Lindahl, L. (2011). Improving the school-to-work transition for vocational students - what can we learn from research? Swedish Institute for Social Research (SOFI), Working Paper 13/2011.

Marten, C., Neyer, G., \& Ostner, I. (2012). Neue soziale Risiken, neue Politiken-Familienpolitischer Wandel in Deutschland, Österreich und der Schweiz. In H. Bertram \& M. Bujard (Eds.), Soziale Welt. Sonderband 19. Zeit, Geld, Infrastruktur. Zur Zukunft der Familienpolitik (pp. 115-138).

Martín-García, T., \& Baizan, P. (2006). The impact of the type of education and of educational enrolment on first births. European Sociological Review, 22, 259-275.

Maul, K. (2012). Der Einfluss der beruflichen Tätigkeit auf die Familiengründung. Würzburg: Ergon Verlag.

Michelmore, K., \& Musick, K. (2014). Fertility patterns of college graduates by field of study, US women born 1960-79. Population Studies, 68, 359-374.

Neyer, G. (2003). Family policies and low fertility in Western Europe. Journal of Population and Social Security (Population), 1, Supplement: 46-93, http://www.ipss.go.jp/webj-ad/webjournal.files/population/ps03_06.asp

Neyer, G. (2009). Bildung und Kinderlosigkeit in Österreich und in Schweden. Zeitschrift für Familienforschung, 21, 286-309.

Neyer, G. (2010). Familienpolitik in Österreich zwischen Beharrung und Veränderung. Revue d'Allemagne et des pays de langue allemande, 42, 57-70.

Neyer, G., \& Hoem, J. M. (2008). Education and permanent childlessness: Austria vs. Sweden. A research note: In J. Surkyn, P. Deboorsere, \& J. Van Bavel (Eds.), Demographic challenges for the 21st century. A state of the art in demography (pp. 91-112). Brussels: VUP Press.

Neyer, G., Hoem, J. M., \& Andersson, G. (2013). Kinderlosigkeit, Bildungsrichtung und Bildungsniveau. Ergebnisse einer Untersuchung schwedischer und österreichischer Frauen der Geburtenjahrgänge 1955-59. In D. Konietzka \& M. Kreyenfeld (Eds.), Ein Leben ohne Kinder. Ausmaß, Strukturen und Ursachen von Kinderlosigkeit (pp. 101-135). Wiesbaden: Springer VS.

Obinger, H., \& Tálos, E. (2010). Janus-faced developments in a prototypical Bismarckian welfare state. Welfare reforms in Austria since the 1970s. In B. Palier (Ed.), A long goodbye to Bismarck? The politics of welfare reform in continental Europe (pp. 101-128). Amsterdam: Amsterdam University Press.

Oláh, L. S., \& Bernhardt, E. (2008). Sweden: Combining childbearing and gender equality. Demographic Research, 19, 1105-1144. http://www.demographic-research.org/volumes/ vol19/28/19-28.pdf 
Oláh, L. S., \& Hobson, B. (2006). Birthstrikes? Agency and capabilities in the reconciliation of employment and family. Marriage and Family Review, 39, 197-227.

Ohlsson-Wijk, S. (2015). Family formation at the turn of the new millenium (Stockholm University Demography Unit Dissertation Series 13). Stockholm: Acta Universitatis Stockholmiensis.

Oppenheimer, V. K. (1994). Women's rising employment and the future of the family in industrial societies. Population and Development Review, 20, 293-342.

Prskawetz, A., Sobotka, T., Buber, I., Engelhardt, H., \& Gisser, R. (2008). Austria: Persistent low fertility since the mid-1980s. Demographic Research, 19, 293-360. http://www.demographicresearch.org/volumes/vol19/12/19-12.pdf

Rindfuss, R. R., \& Bumpass, L. L. (1976). How old is too old? Age and the sociology of fertility. Family Planning Perspectives, 8, 226-230.

Rindfuss, R. R., Morgan, S. P., \& Offutt, K. (1996). Education and the changing age pattern of American fertility: 1963-1989. Demography, 33, 277-290.

Rösler, W. (2012). Strukturwandel und Fertilität. Wie die höhere Berufsbildung der Frau die Geburtenrate beeinflusst. Quantitative Analysen im Zeitverlauf des „zweiten demografischen Übergangs “, Dissertation. Humboldt University, Berlin.

Rønsen, M., \& Skrede, K. (2010). Can public policies sustain fertility in the Nordic countries?. Demographic Research 22, 321-346. http://www.demographic-research.org/Volumes/ Vol22/13/22-13.pdf

Seidl, M. (1993). Einkommensunterschiede zwischen Männern und Frauen im Bundesdienst. Wien: Wirtschaftsuniversität (Diplomarbeit).

Smyth, E. (2003). Gender differentiation and early labour market integration across Europe. In I. Kogan \& W. Müller (Eds.), School-to-work transitions in Europe: Analyses of the EU LFS 2000 Ad Hoc Module (pp. 55-88). Mannheim: Mannheimer Zentrum für Europäische Sozialforschung.

Statistik Austria. (2014). Kindertagesheimstatistik 2013/2014. Wien.

Surkyn, J., \& Lesthaeghe, R. (2004). Value orientation and the second demographic transition (SDT) in Northern, Western and Southern Europe: An update. In G. Andersson \& G. Neyer (Eds.), Contemporary research on European fertility: Perspectives and developments. Demographic Research. Special Collection 3 (pp. 43-86). http://www.demographic-research. org/special/3/3/s3-3.pdf

Tesching, K. (2012). Education and fertility. Dynamic interrelations between women's educational level, educational field and fertility in Sweden. (Stockholm University Demography Unit Dissertation Series 6). Stockholm: Acta Universitatis Stockholmiensis.

van Bavel, J. (2010). Choice of study discipline and the postponement of motherhood in Europe: The impact of expected earnings, gender composition, and family attitudes. Demography, 47, 439-458.

van de Kaa, D. J. (1996). Anchored narratives: The story and findings of half a century of research into the determinants of fertility. Population Studies, 50, 389-432.

Open Access This chapter is distributed under the terms of the Creative Commons Attribution 4.0 International License (http://creativecommons.org/licenses/by/4.0/), which permits use, duplication, adaptation, distribution and reproduction in any medium or format, as long as you give appropriate credit to the original author(s) and the source, provide a link to the Creative Commons license and indicate if changes were made.

The images or other third party material in this chapter are included in the work's Creative Commons license, unless indicated otherwise in the credit line; if such material is not included in the work's Creative Commons license and the respective action is not permitted by statutory regulation, users will need to obtain permission from the license holder to duplicate, adapt or reproduce the material.

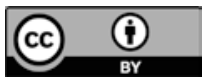

